\title{
Effect of Multiple Intelligences Instructional Strategy on Achievement and Retention in Mole Concept Among Chemistry Students in Abuja, Nigeria
}

\author{
Ojiyi C. A $^{1^{*}}$ and Agu P. A. ${ }^{2}$ \\ ${ }^{1}$ Faculty of Education, Nasarawa State University, Keffi \\ *correspondence: 0juyi C. A; kateobiabo1@gmail.com
}

\begin{abstract}
This study examined the Effect of Multiple Intelligences Instructional Strategy (MIIS) on Achievement and Retention in Mole Concept among Chemistry Students in Abuja, Nigeria. Quasi experimental, pre-test, post-test, and post post-test control group design was adopted for this study. Two research questions guided the study and two hypotheses were tested at 0.05 level of significance. The population of the study was senior secondary school chemistry students in Abuja, Nigeria. The sample for the study was two co-educational schools. One served as the experimental group and the other served as the control group. Mole Concept Achievement Test (MCAT) (KR-21 = 0.70) was used for data collection. Descriptive statistics of mean and standard deviation was used to answer the research question, while null hypotheses were tested using ANCOVA at 0.05 level of significance. The result of the study reveals that, there was significant difference between the mean achievement scores of students taught the mole concept using multiple intelligences instructional strategy (MIIS) and those taught using lecture method. There was a significant difference between the mean retention scores of chemistry students taught the mole concept using MIIS and conventional method. Based on the findings of this study, the following recommendations have been made; there is a need for curriculum developers to develop appropriate curriculum that will make provision for the teacher to adopt various activities that will appeal to each students' learning style or intelligence to enable them learn effectively.
\end{abstract}

Keywords: effect; multiple intelligences; instructional strategy; achievement; retention; mole concept

\section{INTRODUCTION}

Science in partnership with Technology has influenced the way people live. Science is the systematic way of acquiring knowledge through observation and experimentation, whereas technology is the practical application of science. Enaiyeju and Jibril (2014) defined science and technology education as the field concerned with sharing science and technology contents and processes with children, college students or adults within the general public. Oyegun, (2013) opined that science and technology are the basic tools for industrial and national development. If science and technology are appropriated usefully, they could bring positive social change to any nation. The teaching of science is split into the discipline of Chemistry, Physics and Biology at the senior secondary school level in Nigeria. The focal subject in this study is Chemistry. Chemistry is defined as the study of matter, its properties, how and why substances combine or separate to form other substances, and how substances interact with energy (Bagley, 2017). Chemistry is one of the main science subjects in the secondary school curriculum which is very important for undertaking major careers such as Medicine, Pharmacy and Nursing at the tertiary level of education in Nigeria (Ajayi \& Ogbeba, 2017). To enroll in chemistry related careers, a student will need to pass chemistry at the credit level in Senior Secondary Certificate Examinations (SSCE) conducted by West African Examinations Council (WAEC). Despite the relevance of chemistry in career choice of science students, the number of students achieving credit passes in the SSCE examinations is not as high as desired. According to Collins Dictionary, achievement is "something which someone has become successful in doing, particularly after exerting much energy. Learning achievement refers to the outcomes or gains from instructional delivery.

Poor achievement of students in chemistry has always been a course of concern to all, particularly in chemistry as a subject (Adamu, Boris \& Kenni 2013). Lamidi, Oyelekan and Olorundare (2015) posited that the Nigerian chemistry candidates have been performing below expectation in the School Certificate Chemistry Examinations by the West African Examination Councils. Understanding the mole concept could help improve students' performance in chemistry since the mole concept can be applied to other chemistry topics.

Ajayi (2013) reported that several researchers such as Olorunyomi (2013) and Olorundare (2014) reported that the causes of Students' poor achievement in SSCE physical chemistry concepts such as the mole includes a major factor such as using inefficient teaching methods to teach difficult chemistry concepts such as the mole concept.

This situation of low achievement of students in chemistry has stopped many students of science from furthering their educational careers in areas such as Medicine, Pharmacy, Chemistry, and science teaching. 
The performance of chemistry students in the WAEC examinations has consistently been poor (Ojukwu, 2016).

Table1 shows performance of chemistry candidates at the West African Examinations Council for the past five years Analysis of the SSCE chemistry results from $2013-2017$ shows that out of 105,453 that sat for Chemistry in all secondary schools in Abuja, 26,680 passed at credit level.
This implies that only about one student out of four was qualified to gain admission into tertiary level institutions to study chemistry related courses. The chief examiner's reports of WAEC, 2013 -2017 indicate poor performance of students in the sciences particularly chemistry. This calls for urgent attention if Nigeria is to meet up with the challenging and rapidly growing wealth of scientific knowledge.

TABLE 1: Performance of WASSCE Chemistry Candidates (2014-2018)

\begin{tabular}{cccc}
\hline Year & Total Students (N) & $\begin{array}{c}\text { Credit Pass } \\
\text { Number (\%) }\end{array}$ & $\begin{array}{c}\text { Fail grade (D7-F9) } \\
\text { Number (\%) }\end{array}$ \\
\hline 2014 & 565,692 & 49.54 & 50.46 \\
2015 & 611,687 & 44.23 & 55.76 \\
2016 & 627,302 & 43.13 & 56.87 \\
2017 & 653442 & 31.00 & 69.00 \\
2018 & 745322 & 43.27 & 56.73 \\
\hline
\end{tabular}

Source: WAEC Research and Statistics Unit, Annual WAEC Report 2018, Lagos

Thus, the trend in performance was poor for most of the years under review. Among the many factors that are responsible for such poor performance as reported by WAEC examiners report, include; poor mathematical skills; lack of communication skills and lack of laboratory skills. Jack, Danjuma and Abdul-Kadir (2017) indicated that students perform poorly in chemistry due to factors such as lack of qualified teachers, unavailability of laboratory equipment, overloaded curriculum involving many calculations and students' perception of chemistry as a difficult subject. In addition, studies in Nigeria (Opara \& Waswa, 2013; Muhammad, 2014) suggested that teachers tend to rush through the scheme of work to enable them cover the topics in the curriculum within the school year leaving the students without grasping the necessary chemistry concepts.

Many students find it difficult to understand chemistry as a subject because it contains abstract concepts such as mole, molecule and particle. The mole concept is among the most important topics in chemistry that students find very difficult to understand (Arya \& Kumar, 2018). Students find other chemistry concepts difficult if they do not understand the mole concept. Hence, students' answers are always wrong in stoichiometry because those calculations in chemical equations are hinged on the mole concept. The mole is the unit of measurement in the International System of Units (SI) for an amount of substance. It is defined as the amount of a chemical substance that contains as many elementary entities, e.g., atoms, molecules, ions, electrons, or photons, as there are atoms in 12 grams of carbon-12 (C) which is the isotope of carbon with relative atomic mass 12 . Due to the difficulty of the mole concept, more innovative instructional methods of teaching could be tried to teach this concept. Among these innovative methods is Multiple Intelligences Instructional Strategy which could enhance students' interest to learn mole which tends to be abstract and difficult.

Retention of the concepts taught can affect achievement positively or negatively. Tyopav, (2013) defined retention as the ability to remember experiences of things learned. Retention is the ability to retain in the memory and remember things learned through effective understanding. Therefore, to improve students' achievement level in the mole concept, the researcher will suggest that it is necessary to improve the level at which they retain the concept of the mole acquired by the learner. Hence, this study specifically sought to find out the effect of multiple intelligences instructional strategy on achievement and retention in mole concept among chemistry students in Abuja, Nigeria.

\section{RESEARCH QUESTIONS}

Specifically, this research work sought to answer the following research questions:

1. What are the mean achievement scores of students taught the mole concept using Multiple Intelligence Instructional Strategies (MIIS) and conventional method?

2. What are the mean retention scores of chemistry students taught the mole concept using MIIS and conventional method?

\section{STATEMENT OF THE HYPOTHESES}

The following null hypotheses were tested at 0.05 level of significance:

$\mathbf{H}_{\mathbf{0 1}}$ There is no significant difference in the mean scores of students taught the mole concept using Multiple Intelligence Instructional Strategies (MIIS) and those taught using conventional method.

$\mathrm{Ho}_{2}$ There is no significant difference in the mean retention scores of chemistry students taught the mole concept using MIIS and conventional method.

\section{METHODOLOGY}

The study adopted the quasi- experimental design, pretest, post-test and post-post-test, non-equivalent, nonrandomized control design. The Multiple Intelligence Instructional Strategies (MIIS) in this study were the independent variable and treatment while Achievement and Retention as measured by test scores were dependent variables. Multistage sampling technique was used to select the sample for the study. Two schools were selected using a random sampling technique known as hat and 
draw. Two intact classes of SS2 chemistry students were purposively sampled from two co-educational schools for this study. Intact classes of 55 students for experiment and 47 students for control were used for the study. In all, a total sample of 102 students were used for the study Johannes and Mauri (2012) posited that a sample size of thirty (30) subjects is sufficient for an experimental study.

\section{RESULTS}

\section{Research Question One}

What are the mean achievement scores of students taught the mole concept using Multiple Intelligences Instructional Strategy (MIIS) and conventional method? The results are shown in table 4.1.

TABLE 2: Means and Standard Deviations of MCAT Achievement Scores of Students in the Experimental and Control Groups

\begin{tabular}{lcccccc}
\hline \multirow{2}{*}{ Group } & \multirow{N}{*}{} & \multicolumn{2}{c}{ Pre-test } & \multicolumn{2}{c}{ Post-test } & Mean Gain \\
\cline { 3 - 5 } & & Mean & SD & Mean & SD & \\
\hline Experimental & 55 & 13.93 & 2.27 & 22.76 & 3.90 & 8.83 \\
Control Groups & 47 & 12.09 & 1.99 & 18.96 & 2.87 & 6.87 \\
\hline
\end{tabular}

TABLE 2 shows the mean achievement scores of students taught mole concept using multiple intelligences instructional strategy and conventional method. The results from the table indicate that for the experimental and control groups, the mean achievement scores of 8.83 and 6.87 were obtained for multiple intelligences instructional strategy and conventional method while the standard deviation values were given as 1.63 and 0.87 respectively.

\section{Hypothesis One}

There is no significant difference in the mean achievement scores of students taught the mole concept using Multiple Intelligence Instructional Strategy (MIIS) and those taught using conventional method.

TABLE 3: Analysis of Co-variance Showing significant Difference between the Mean scores of Students Taught the Mole Concept using Multiple Intelligences Instructional Strategy (MIIS) and those Taught using Lecture method

\begin{tabular}{lccccc}
\hline \multicolumn{1}{c}{ Source } & Type III Sum of Squares & df & Mean Square & F & Sig. \\
\hline Corrected Model & $452.599 \mathrm{a}$ & 12 & 37.717 & 3.012 & .001 \\
Intercept & 19839.693 & 1 & 19839.693 & 1584.482 & .000 \\
Pre-test & 452.599 & 12 & 37.717 & 3.012 & .001 \\
Group & 454.518 & 1 & 454.518 & 13.666 & .000 \\
Error & 1114.391 & 89 & 12.521 & & \\
Total & 46591.000 & 102 & & & \\
Corrected Total & 1566.990 & 101 & & & \\
\hline
\end{tabular}

TABLE 3 indicates results of analysis of co-variance showing significant difference between the mean scores of students taught the mole concept using multiple intelligences instructional strategy (MIIS) and those taught using lecture method. It is observed from the table that the F ratio of 13.67 was obtained with associated probability value of 0.000 . Since the associated probability 0.000 was less than 0.05 set as level of significance, the hypothesis was rejected. It therefore implies there is a significant difference between the mean achievement scores of students taught the mole concept using multiple intelligence instructional strategy (MIIS) and those taught using conventional method. In other words, students taught mole concept using multiple intelligences strategy performed significantly better than those taught using conventional method.

\section{Research Question Two}

What are the mean retention scores of chemistry students taught the mole concept using MIIS and conventional method? The results are shown in table 4. 
TABLE 4: Mean Retention Scores of Chemistry Students Taught the Mole Concept Using MIIS and LM

\begin{tabular}{|c|c|c|c|c|}
\hline Group & & Posttest & Retention & Mean Loss \\
\hline & Mean & 23.67 & 15.47 & 8.20 \\
\hline \multirow[t]{3}{*}{ MIIS } & $\mathrm{N}$ & 55 & 55 & \\
\hline & Std. Deviation & 4.44 & 3.85 & \\
\hline & Mean & 18.96 & 13.09 & 5.87 \\
\hline \multirow[t]{2}{*}{ LM } & $\mathrm{N}$ & 47 & 47 & \\
\hline & Std. Deviation & 2.87 & 3.79 & \\
\hline
\end{tabular}

TABLE 4 shows the mean retention scores of students taught mole concept using multiple intelligences instructional strategy and conventional method. The results from the table indicate that at sample sizes of 55 and 47 respectively, the mean retention scores of 8.20 and 5.87 were obtained for students taught mole concept using multiple intelligences instructional strategy and conventional It is observed that the mean retention scores and standard deviation values of students taught mole concept using multiple intelligences instructional strategy was higher than the mean retention scores and standard deviation of those taught mole concept using conventional method. Hence, students taught mole concept using multiple intelligences instructional strategy had higher mean retention scores than those taught using conventional method of teaching.

\section{Hypothesis Two}

There is no significant difference in the mean retention scores of chemistry students taught the mole concept using MIIS and conventional method.

TABLE 5: Analysis of Co-variance Showing significant Difference between the Mean Retention scores of Chemistry Students Taught the Mole Concept Using Multiple Intelligences Strategy and Lecture Method

\begin{tabular}{lccccc}
\hline \multicolumn{1}{c}{ Source } & Type III Sum of Squares & df & Mean Square & F & Sig \\
\hline Corrected Model & $405.269 \mathrm{a}$ & 17 & 23.839 & 3.627 & .000 \\
Intercept & 10524.529 & 1 & 10524.529 & 1601.343 & .000 \\
Post-test & 405.269 & 17 & 23.839 & 3.627 & .000 \\
Group & 62.395 & 1 & 62.395 & 1.832 & .177 \\
Error & 552.075 & 84 & 6.572 & & \\
Total & 19655.000 & 102 & & & \\
Corrected Total & 957.343 & 101 & & & \\
\hline
\end{tabular}

Table 5 indicates results of analysis of co-variance showing significant difference between the mean retention scores of chemistry students taught the mole concept using multiple intelligences instructional strategies (MIIS) and conventional method. It is observed from the table that an F ratio of 1.832 was obtained with associated probability value of 0.177 since the associated probability 0.177 is greater than 0.05 set as level of significance, the hypothesis was not rejected. It therefore implies there is a significant difference between the mean retention scores of chemistry students taught the mole concept using multiple intelligences instructional strategy (MIIS) and conventional method. In other words, the mean retention scores of students taught mole concept using multiple intelligences instructional strategy is significantly higher than those of their counterparts taught mole concept using conventional method.

\section{DISCUSSION}

The findings of this study reveal the effect of multiple intelligences strategy on the achievement and retention in mole concept among chemistry students. The results of hypothesis one reveal significant difference between the mean achievement scores of students taught the mole concept using multiple intelligences instructional strategy (MIIS) and those taught using conventional method. In other words, students taught mole concept using multiple intelligence strategy performed significantly better than those taught using conventional method. The reason for better achieve could be that they become actively engaged and interested in their individual learning process, Also, that students participated more frequently in the lesson due to the use of varieties of activities brought into the lesson by the teacher which appeal to various intelligence, readiness and learning styles.

Findings from the analysis of hypothesis two shows the significant difference between the mean retention scores of chemistry students taught the mole concept using multiple intelligence instructional strategies (MIIS) and conventional method. In other words, the mean retention scores of students taught mole concept using multiple intelligence instructional strategy is higher than those of their counterparts taught mole concept using conventional method. The findings on students' retention scores taught mole concept using multiple intelligence instructional strategy is higher than those of their counterparts taught mole concept using conventional method. This finding is in agreement with Gambari and Yusuf (2017) who reported that conventional methods had negative effects on Physics students' retention. Also other researchers in agreement such as Fatokun, Uzoechi and Eggya (2016); Fatokun and Enaiyeju (2014) reported that using multiple intelligence aided strategy like games to teach and learn chemistry could enhance motivation in students, improve interest in learning, make students utilize what is learnt actively enhance critical thinking and ability to make decision, help 
students to contextualize which is learnt see the reason for learning, enhance students' retention of the learnt materials, transits to growth of the individual which include communication, personal judgment, cooperation and problem solving. From the findings of this research, it can be concluded that the achievement and retention of chemistry student taught mole using multiple intelligences instructional strategy improved significantly.

\section{RECOMMENDATIONS}

Based on the findings of this study, the following recommendations have been made:

1. The study recommended the need for curriculum developers to develop appropriate curriculum that will make provision for chemistry teacher to adopt various activities that will appeal to each students' learning style or intelligence to enable them learn effectively.

2. Chemistry teachers should adopt the MIIS, namely, active learning, collaborative learning, self -assessment, project based learning and authentic instruction which will enable them to cater for the diverse learning styles of students in their classroom

3. Ministries of Education, both State and Federal should organize workshops and seminars and sponsor teachers to attend in service courses on how to improve their teaching skills using five MIIS.

\section{REFERENCE}

[1] Adamu, A.S; Boris, O.O. \&Kenni, A.M. (2013): Trends in students' achievement in senior school certificate examination (SSCE) in Chemistry 2008-2012. International Journal of Science and Research (IJSR), $2(6)$.

[2] Ajayi, O. V. \& Ogbeba, J. (2017). Effect of Gender on Senior Secondary chemistry student's achievement in stoichiometry using hands on - activities. America Journal of educational research. 5(8, 68-81

[3] Ajayi, V. O. (2013). Effect of Hands-On Activities on Senior Secondary Chemistry Students Achievement and Retention in Stoichiometry in Zone C of Benue State (January 16, 2017). Available at SSRN: retrieved from https://ssrn.com/abstract=2992803 or http://dx.doi.org/10.2139/ssrn.2992803 9 January, 2017

[4] Arya, A \& Kumar, A. (2018). Mole Concept and Problems Solving Approaches in Life Sciences. 10.13140/RG.2.2.29899.90406/1

[5] Bagley, M. (2017). Live Science contributor from, http://www.livescience.com/45986-what-ischemistry.html. retrieved 20 August 2018

[6] Fatokun K.V.F, Egya S. O. \& Uzoechi B. C. (2016) Effect of game instructional approach on chemistry students' achievement and retention in periodicity. European journal of research and reflection in educational sciences. 4(7); 29-40

[7] Fatokun, K. V. F. \& Eniayeju, P. A. (2014). Enhancing students achievement, interest and retention in chemistry through an integral teaching/learning approach. British Journal of Education, Society \& Behavioural Science (4)12:1653-1663.
[8] Jack G, U, Danjuma E, \& Abdul-Kadir M A. (2017). Assessment of Conceptual Difficulties in Chemistry Syllabus of the Nigerian Science Curriculum as Perceived by High School College Students. American Journal of Educational Research, 5(7), 710-716 doi:10.12691/education-5-7-3

[9] Johannes W \& Mauri K. A. (2012). Visualizing Social Science Research: Maps, Methods, \& Meaning. Retrieved from https://methods.sagepub.com/book/visualizingsocial-science-research. DOI: https://dx.doi.org/10.4135/9781483384528

[10] Lamidi, B. T. Oyelekan, O. S, Olorundare A. S (2015). Effects of Mastery Learning Instructional Strategy on Senior School Students' Achievement in the Mole Concept. Electronic Journal of Science Education, 19(5).

[11] Muhammad, B.A. (2014) An Evaluation of the Efficacy of Conceptual Instructional method of teaching Practical Chemistry: The case of secondary schools in Zaria Educational zone Kaduna State, Nigeria. African Journal of Education and Technology, 4(1),112-118.

[12] Ojukwu, M.O. (2016). School environment, insecurity, and students' behavior. Retrieved from: http://independent.academia.edu/ojukwumo\&sa=u \&ved=2ahukewihlzdxzc

[13] Olorundare, A. S. (2014). Correlates of poor academic performance of secondary school students in the sciences in Nigeria. Paper presented at the International Institute for Capacity Building in Higher Education, Virginia State University, Virginia, USA. 20th - 31st June, 2014.

[14] Olorunyomi, A. A. (2013). Effect of experiential teaching method on students' achievement in Chemistry. Unpublished M.Ed dissertation, Ekiti State University, Ado Ekiti

[15] Opara, F. \& Waswa, P. (2013) Enhancing students' achievement in Chemistry through the Piagetian Model: The learning Cycle. International Journal for Cross-Disciplinary Subjects in Education (IJCDSE), 4(4),1270- 1278.

[16] Oyegun, M. T. (2013). Education and Science, Technology. Journal of Research in Science Teaching, 11(2), 111-115.

[17] Tyopav, T. T. (2013). Impact of field-trip on students' achievement and retention in Geography at senior secondary school level in Katsina-ala Local Government Area of Benue State. Unpublished Master Dissertation. Benue State University, Makurdi.

[18] Yusuf, O. M \& Gambari, A. I. (2017). Relative Effectiveness of Computer-Supported Jigsaw II, STAD and TAI Cooperative Learning Strategies on Performance, Attitude, and Retention of Secondary School Students in Physic. Journal of Peer Learning (2017) 10: 76-94 